\title{
Using Ecological Approach to Prediction Girls` Physical Activity
}

Hamidzadeh Sani, Z, S. (M.A). Allameh Tabataba'i University, Tehran, Iran

Poor Aghaei, Z. (Ph.D). Allameh Tabataba'i University, Tehran, Iran

Salman, Z. (Ph.D). Allameh Tabataba'i University, Tehran, Iran

Received: 2017 - 9 - 12

Accept: $2018-9-3$

\section{Abstract}

In this correlational study, physical activity of girls' has been predicted using ecological approach. For this purpose, 374 girls aged 10-12 years selected and completed Self-report questionnaire and physical activity children with reminders 7 days (PAQ-C), Perceived physical competence questionnaire (PPFS), Perceived School Climate Questionnaire for physical activity (Am \& et al,2005) and Social Support Questionnaire (Grier and et al, 2008). The BMI index and Lincoln Oseretsky Motor Skills Test was calculated for all subjects. Multiple regression analysis showed Children's fitness, physical competence, perceived climate of the physical environment and social support of friends and family (social environment) are significant predictors for amount of children's physical activity $(P<0.5)$. In this regard, based on effect coefficients it would be say that Fitness $(10 \%)$, physical competence (15\%), Motor Skills (12\%), physical environment $(23 \%)$ and social environment $(24 \%)$ can predict children's physical activity. According to results, it would be suggested using the well- known ecological variables to predict children's activities.

Keywords: physical activity, fitness, Motor Skills, Physical Competence, Physical and Social Environment 


\title{
استفاده از رويكرد بومشناختى به منظور يشبينى فعاليت بدنى دختران
}

\author{
زهره سادات حميدزاده ثانى *، زهرا يور آقايى ا***، زهرا سلمان**** \\ كارشناس ارشد تربيتبدنى، دانشكاه علامه طباطبايى \\ دكترى رفتار حركتى ، عضو هيات علمى دانشخاه علامه طباطبايى

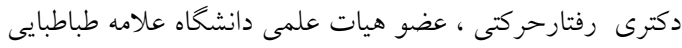

در اين تحقيق با استفاده از يك مطالعه همبستكى فعاليت بدنى كودكان دختر با رويكرد بومشناختى مورد بيشبينى قرار

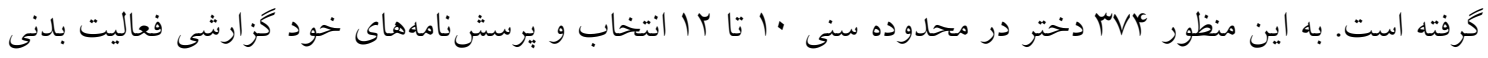

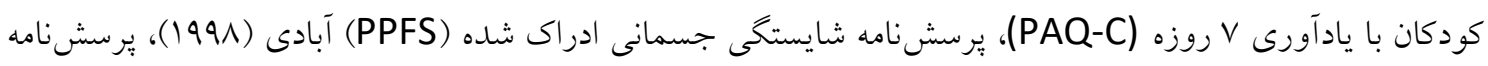

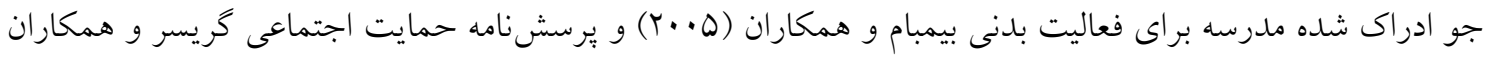

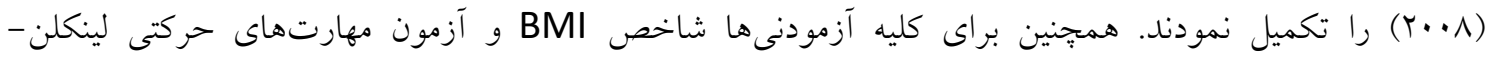

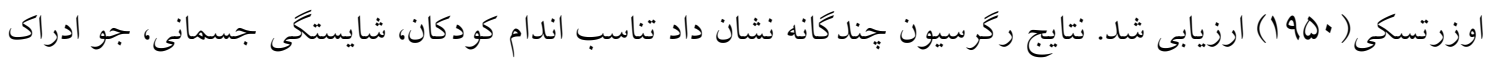

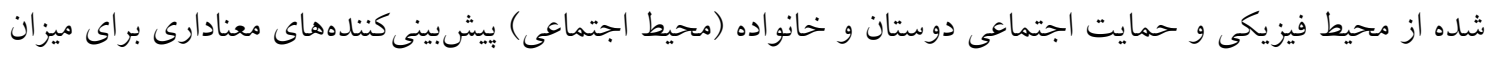

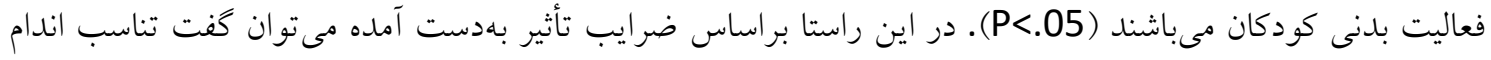

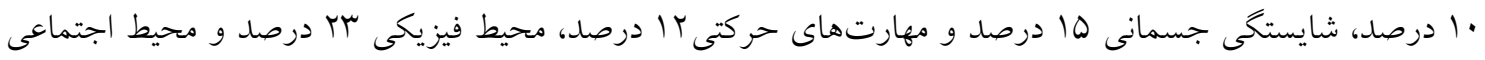

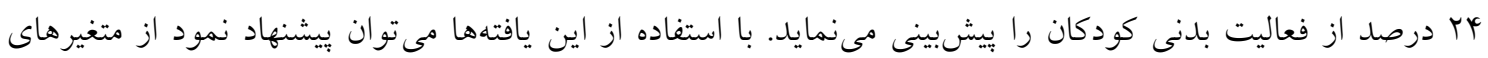
شناخته شده رويكرد بومشناختى براى ييشبينى فعاليت كودكان استفاده شود.

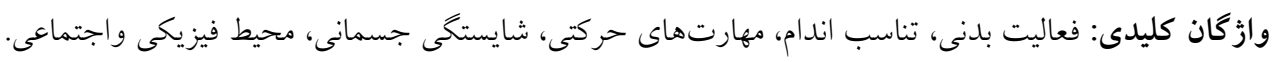


فو ايد تحرى و فعاليتهاى بدنى بر كسى يوشيده نيست؛ به نحوى كه زندكى بدون تحرى بهعنوان يكى از عوامل خطر بالقوه اصلى

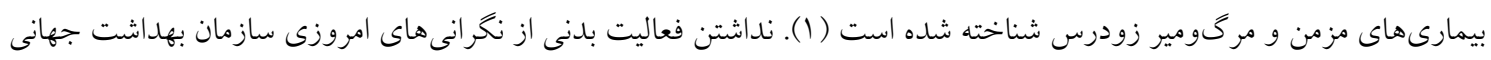

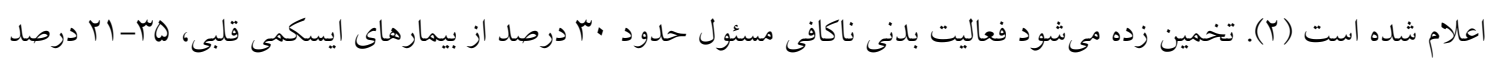

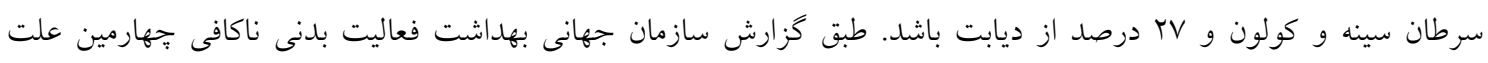

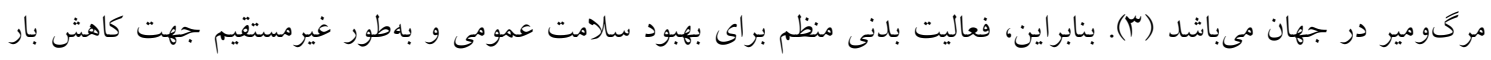

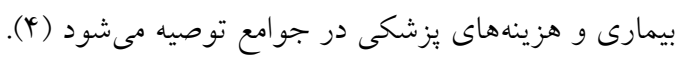

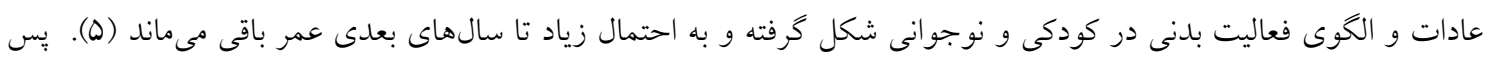

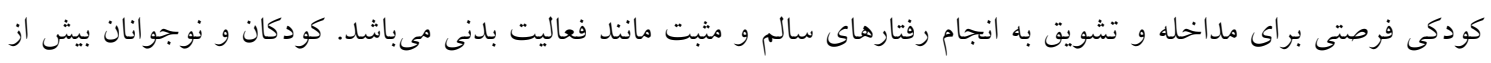

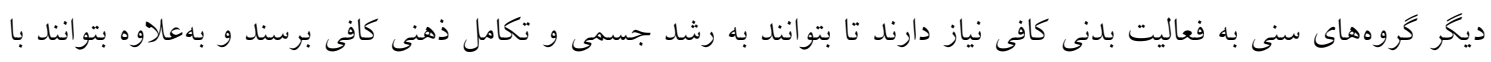

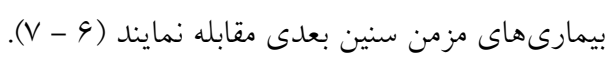

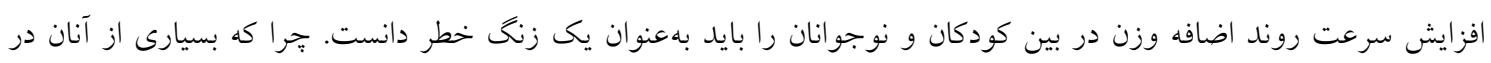

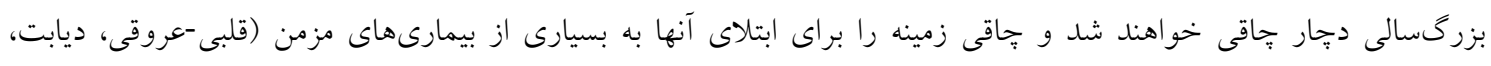

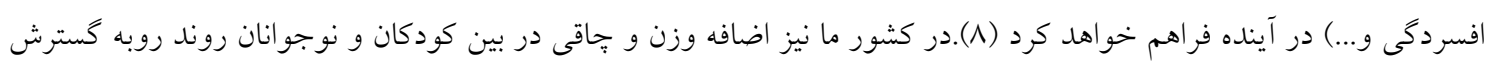

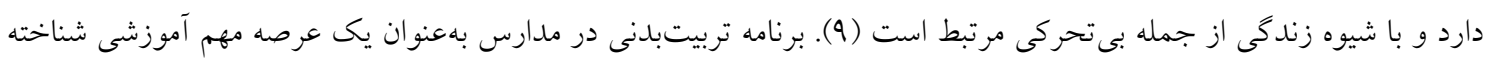

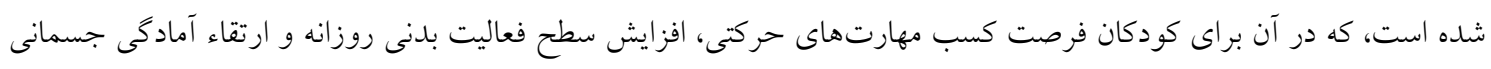

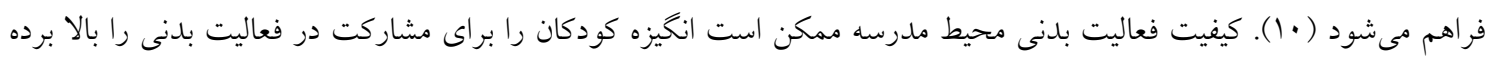

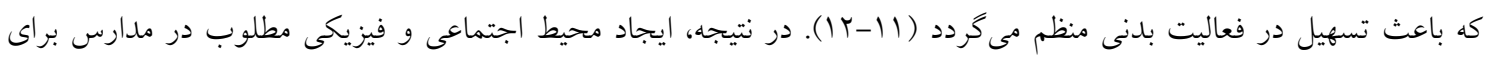

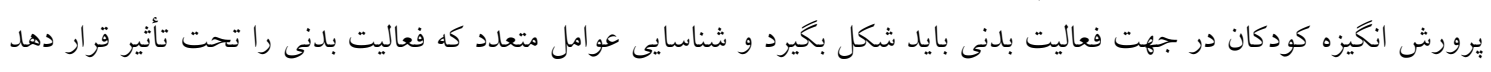

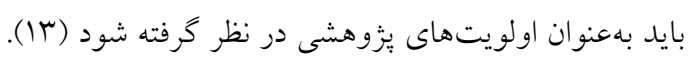

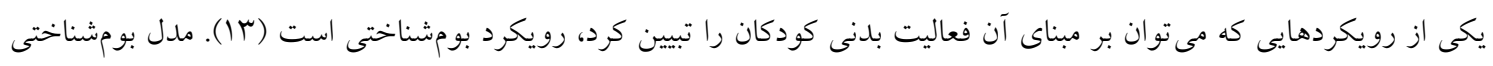

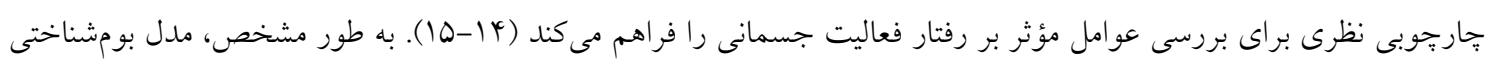

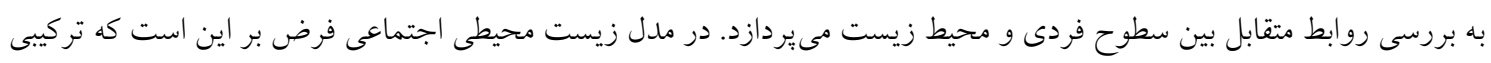

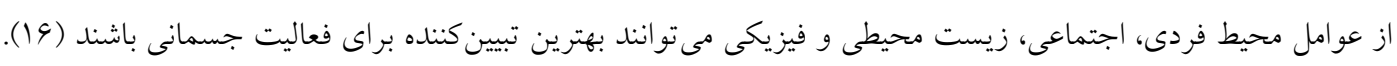

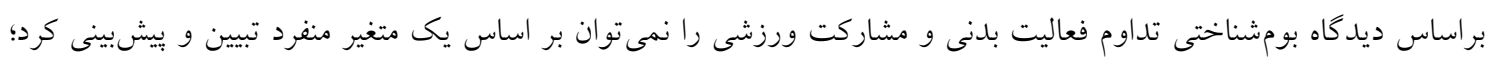

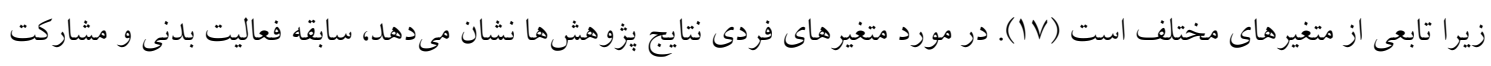

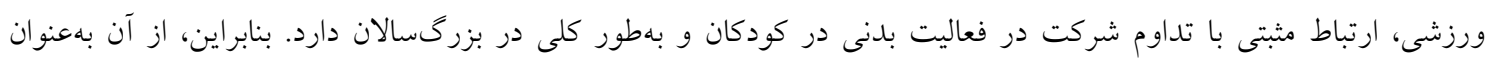

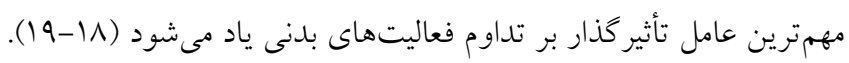

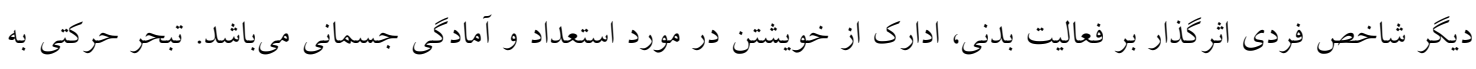

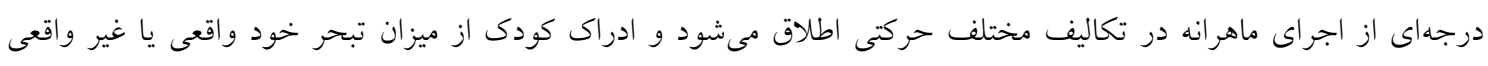

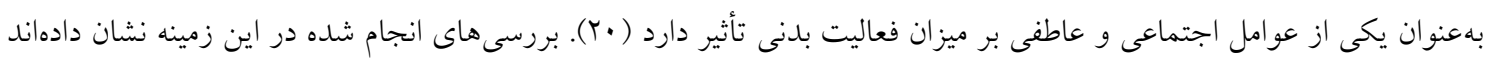

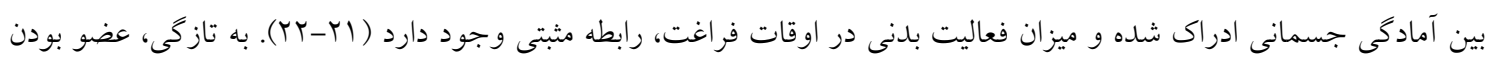

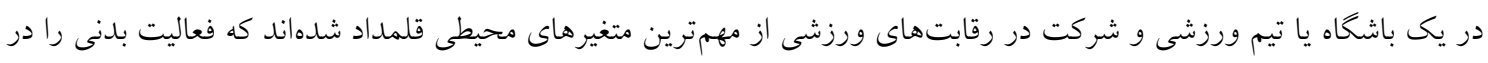

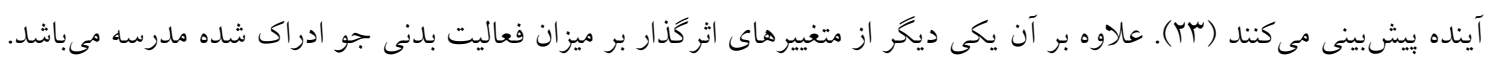

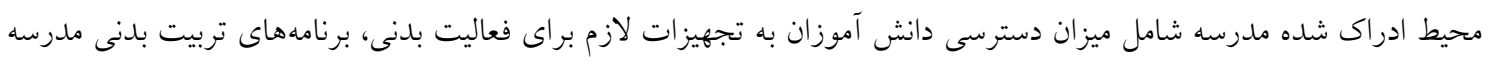

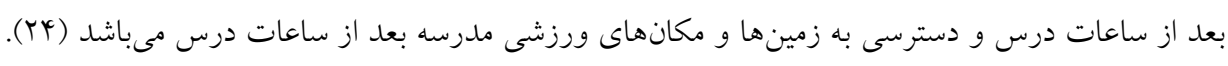


حمايت اجتماعى فيزيكى شامل عواملى هستند كه بر شكل گيرى رفتار فرد مؤثر هستتند. اين عوامل شامل الكوهاى اجبارى، كنترل

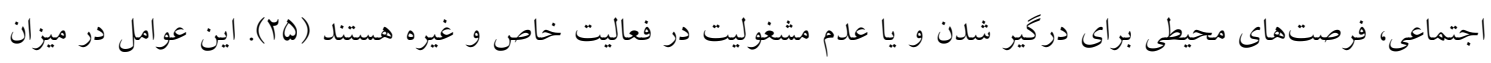

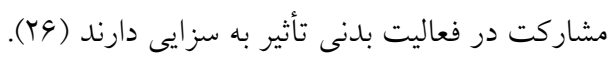

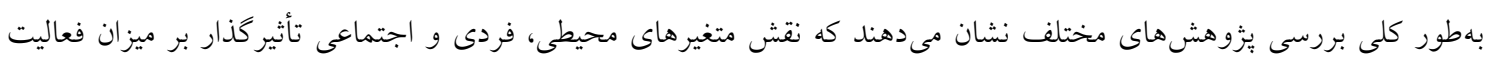

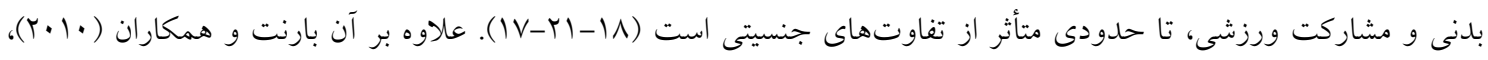

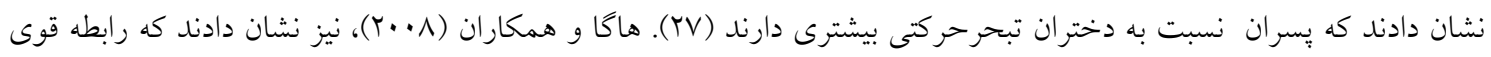

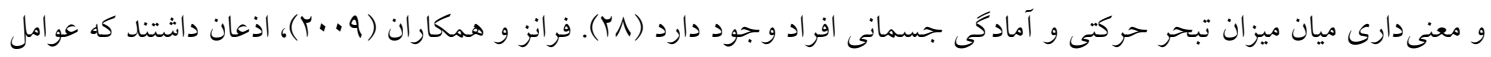

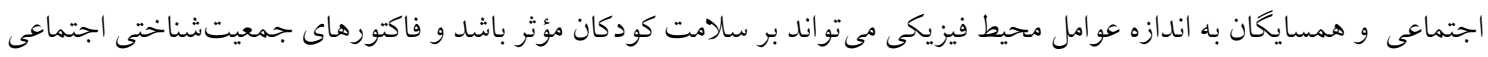

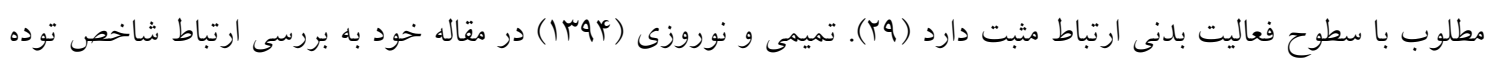

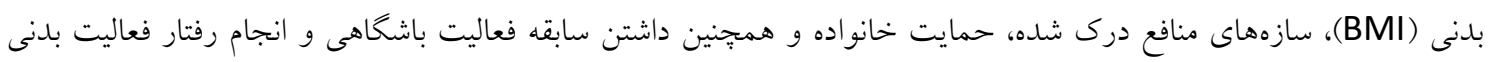

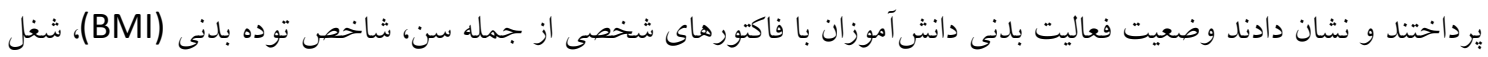
و تحصيلات والدين رابطه معنىدارى نداشت، در حالى كه سابقه انجام فعاليت بدنى با انجام رفتار فعاليت بلدنى رابطه معنى دارى

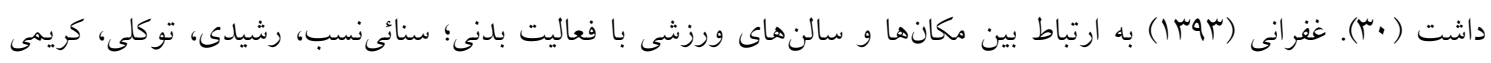

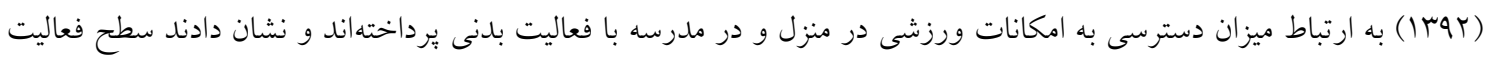

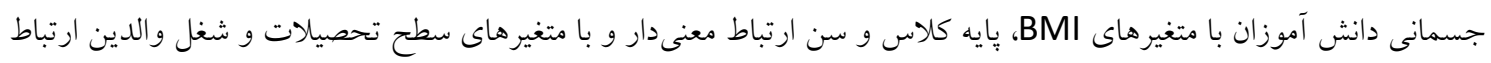

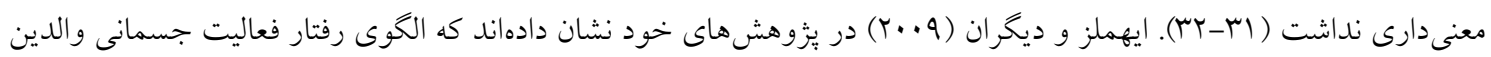

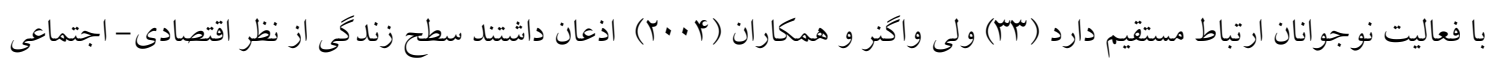

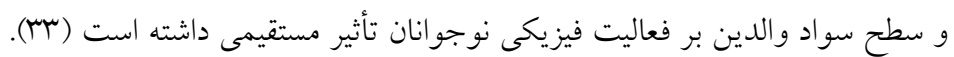

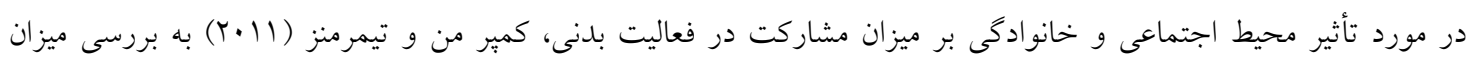

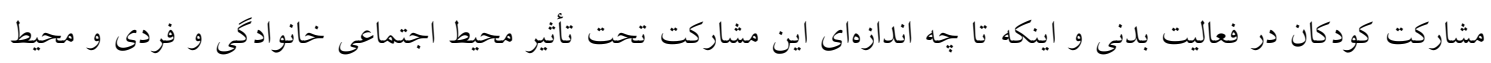

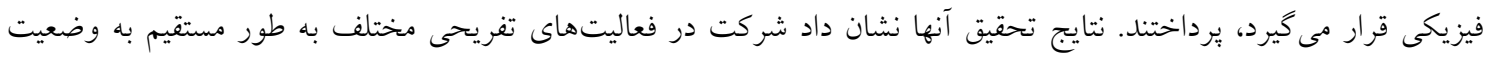

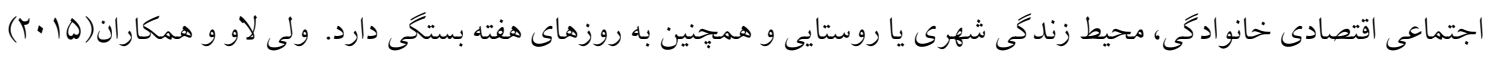

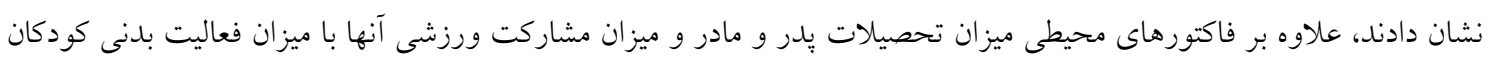

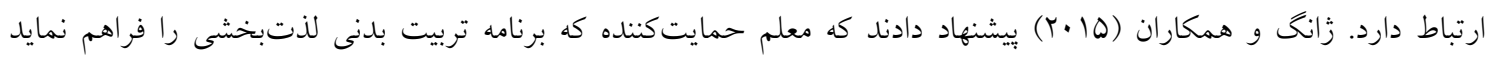

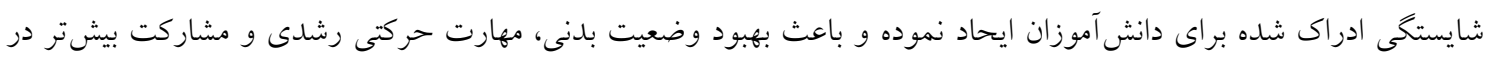

$$
\text { فعاليت بدنى مىشود (I ) (I ). }
$$

اغلب يزوهشهاى انجام شده درباره عوامل مؤثر بر فعاليت بدنى، تنها به بررسى يكى از جنبههاى فردى، اجتماعى يا محيطى

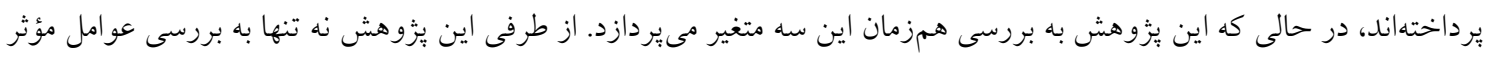

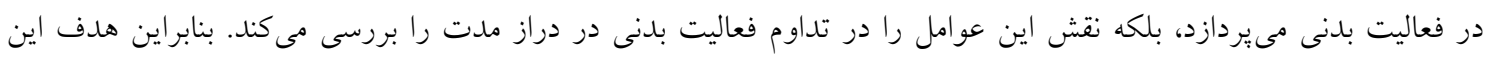

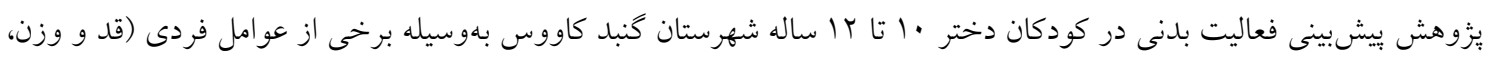

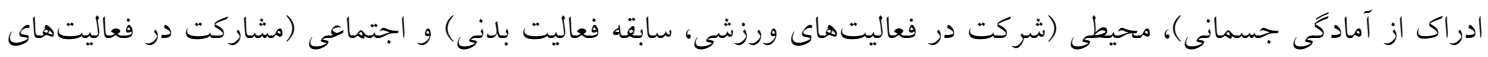

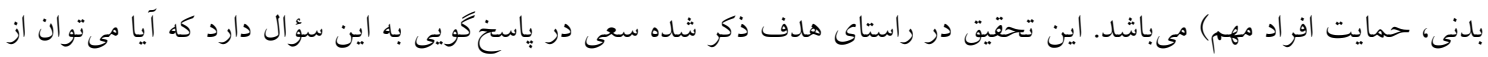

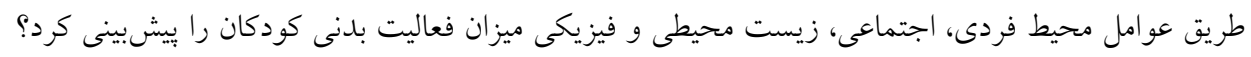

تحقيق حاضر از نوع همبستكى با رويكرد بيشبينى بود، كه به بررسى رابطه ميان متغيرهاى شايستى جسمانى ادراك شده، جو

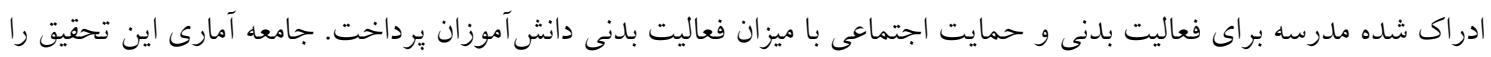

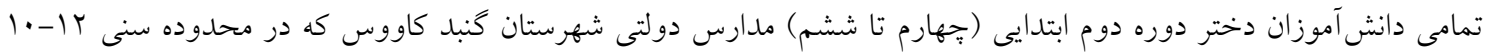




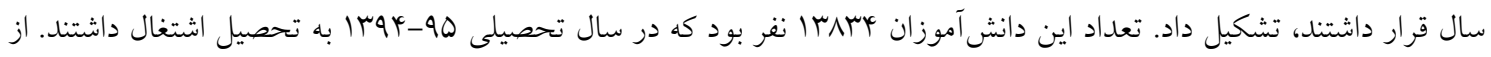

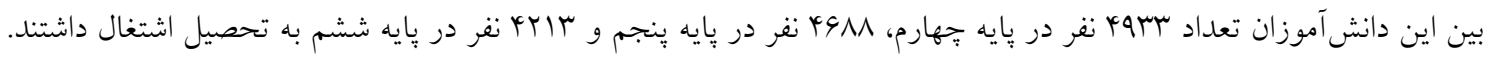

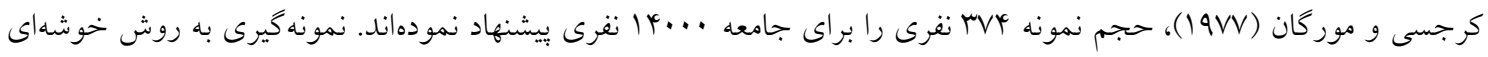
طبقهبندى شده صورت گرفت به اين صورت كه ابتدا نام مدارس ليست شده و با توجه به منطقه جغرافيايى مدارس وك مدرسه

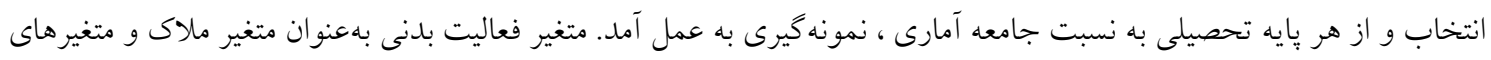
بومشناختى كه شامل تناسب اندام، مهارتهاى حركتى، شايستى جسمانى، محيط فيزيكى و محيط اجتماعى مىباشد، به بهنوان متغيرهاى بيشبين درنظر كرفته شدهاند. براى جمع آورى دادهها از يرسشنامههاى استاندارد به شرح زير استفاده شد:

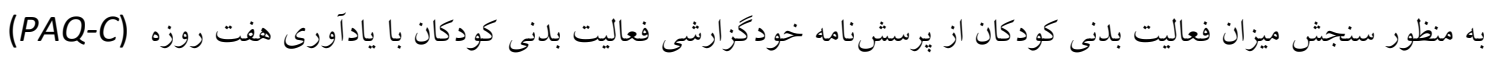

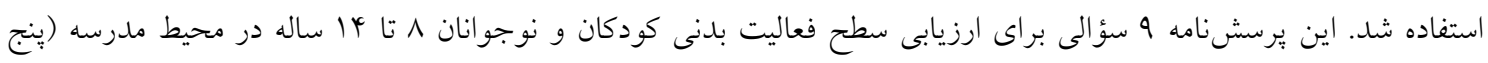

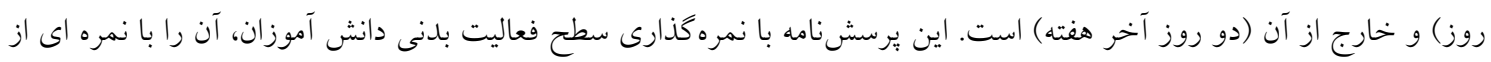

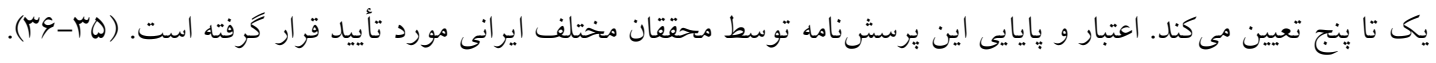

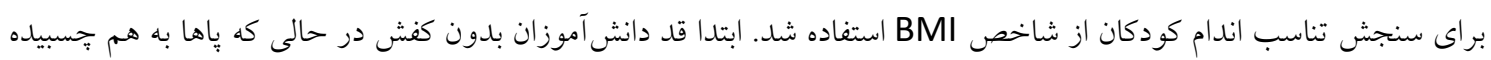

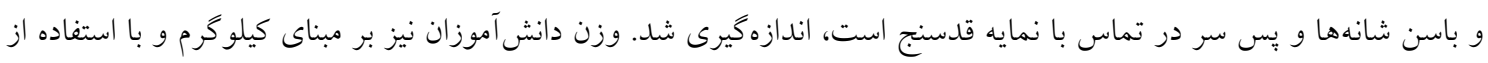

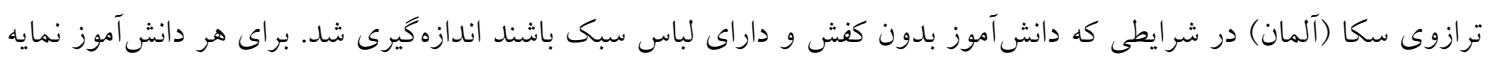
توده بدن به صورت نسبت وزن (بر حسب كيلو گرم) تقسيم بر توان دو قد (برحسب متر) محاسبه گرديد. همجنين تعيين اضافه

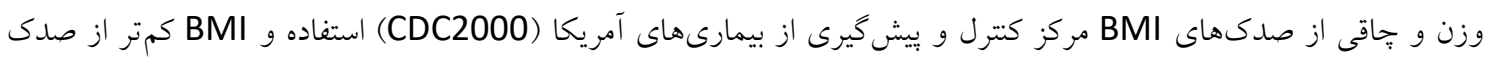
ينج براى سن و جنس به عنوان لاغر، BMI بين صدى هم تا هو بهعنوان اضافه وزن و BMI بالاتر از صدى هو به بهعنوان جاق تعريف شده است (ه山).

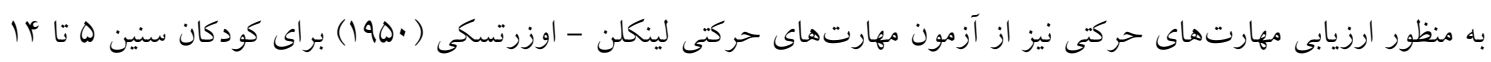

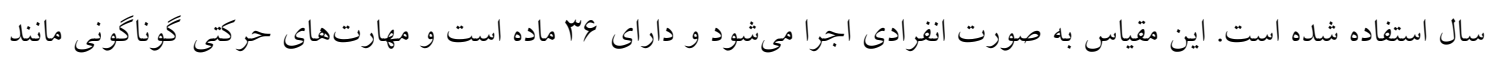
مهارت انخشتان، هماهنكى جشم - دست و فعاليتهاى عضلات بزرگ، دستها، ياها و تنه را مورد بررسى و اندازه گيرى قرار

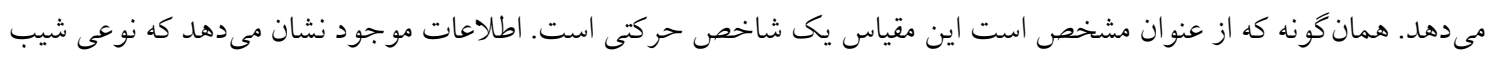

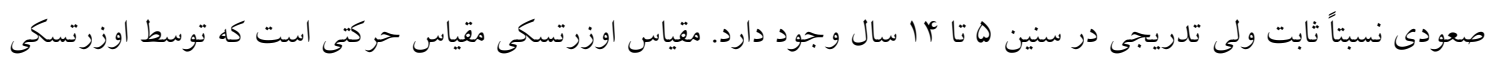

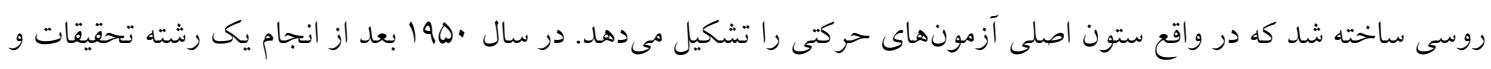

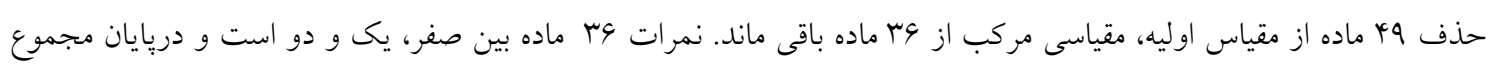

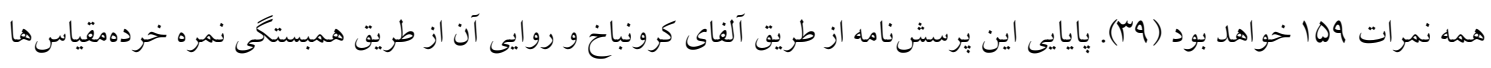

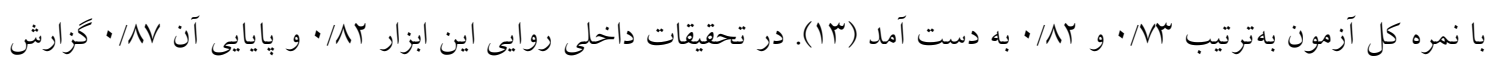

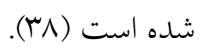

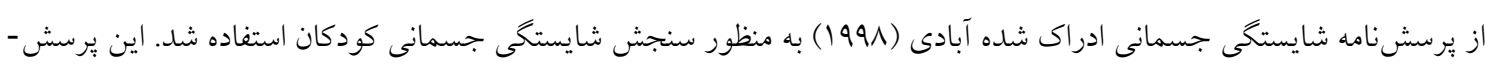

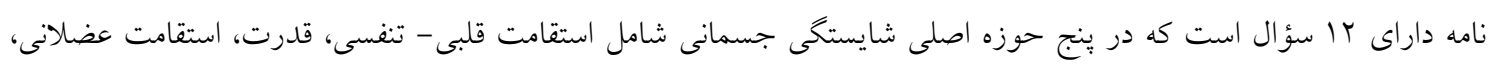

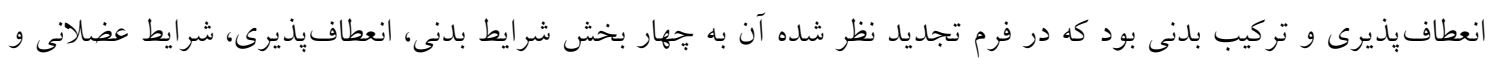

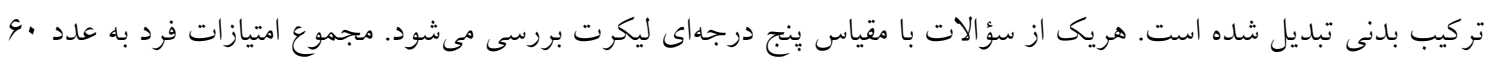

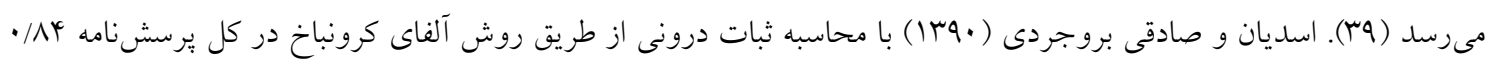

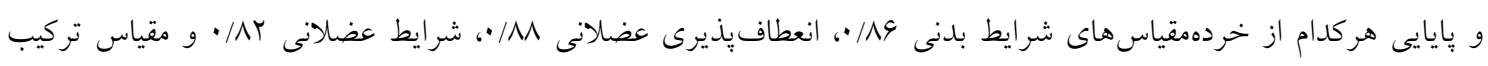

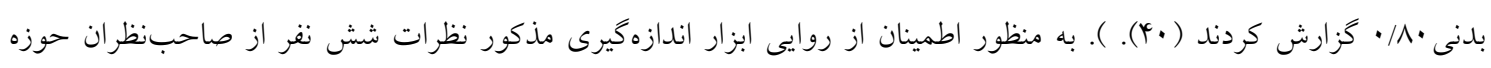

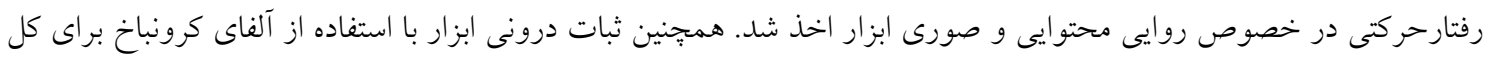

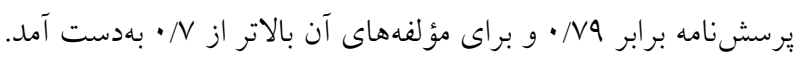


همجنين براى سنجش اثرات محيط فيزيكى از جو ادراك شده مدرسه براى فعاليت بدنى بيمبام و همكاران (ه · (Y) استفاده شده كه از ينج ماده براى سنجش جو ادراك شده از سوى معلمان (r ماده) و جو ادراك شده از سوى همسالان (r ماده) تشكيل شده

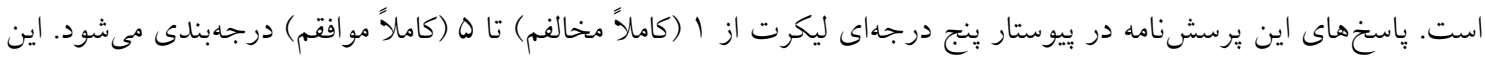
مقياس در راستاى برنامه بهبود برنامه تربيت بدنى در مدارس مقطع متوسطه ايالات متحده ساخته شده است. قاسمنزاد ( •وس إ) پايايى اين ابزار را بهوسيله آلفاى كرونباخ براى جو ادراى شده از سوى معلمان 94/ • و براى جو ادراك شده از سوى همسالان

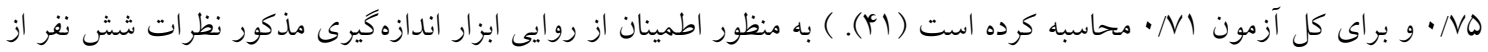
صاحبنظران حوزه رفتارحركتى در خصوص روايى محتوايى و صورى ابزار اخذ شد. همجنين ثبات درونى ابزار با استفاده از

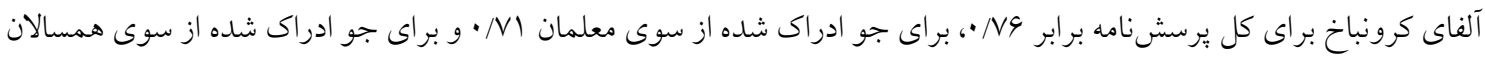
(NY

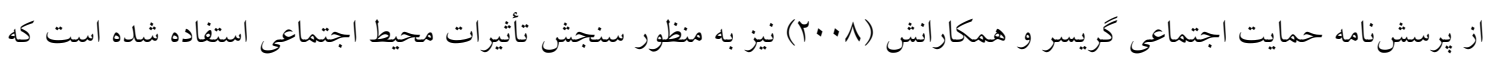

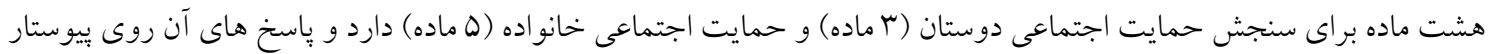
ينج درجهاى ليكرت از ا(هيج وقت) تا ه (هر روز) درجهبندى مىشود. قاسمنزاد (·وبا) اين برسشنامه را ترجمه و روايى و

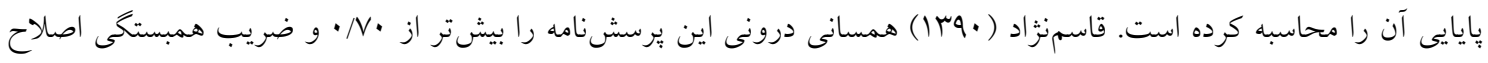

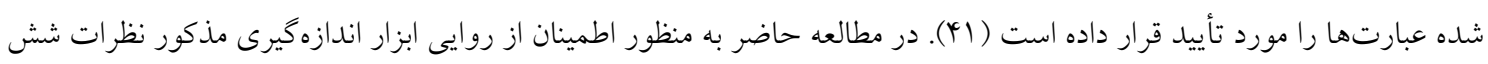
نفر از صاحبنظران حوزه رفتارحركتى در خصوص روايى محتوايى و صورى ابزار اخذ شد. همجنين ثبات درونى ابزار با استفاده

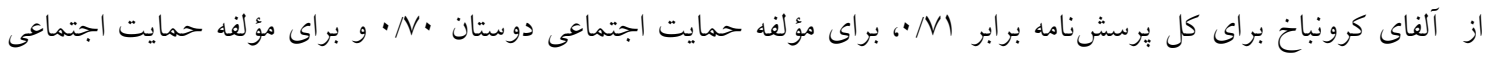
خانو اده NY • بلمدست آمد. يس از غربالكرى دادههاى خام به اطمينان از صحت و تعيين اينكه آيا داده به طور معمول توزيع شده است، از ضريب آلفاى كرونباخ براى تعيين بايايى برسشنامههاى هر مقياس استفاده شد. براى توصيف دادهها از فراوانى، درصد، ميانخين، انحراف معيار و براى آزمون فرضيات از ضريب همبستكى يِيرسون و ركرسيون جندراهـ همزمان استفاده شد. تحليل آمارى نيز با استفاده از نرمافزار SPSS نسخه ب انجام شده است.

\section{يافتهها}

يّيش از بررسى مفروضات تحقيق ضرورى است تا هريك از متغيرها توصيف شوند. جدول (1) ميانگين و انحراف معيار متغيرهاى

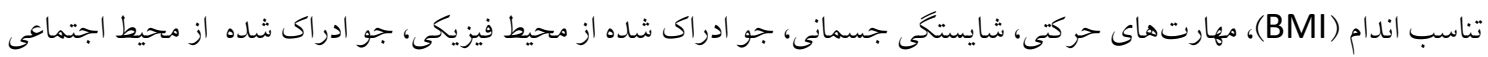
و فعاليت بدنى كودكان را نشان داده است.

جدول ا. ميانخين و انحر اف معيار نمرات متغيرها (n=374)

\begin{tabular}{|c|c|c|}
\hline \multicolumn{2}{|c|}{ ميانكين × انحراف } & بايه تحصيلى \\
\hline$V / V Q \pm$ & $r v / 4 q$ & 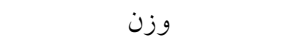 \\
\hline $9 / 0 Y \pm$ & $\mid Y Y / D Q$ & قد \\
\hline$r / 9 Y^{\prime} \pm$ & $M / N Y$ & تناسب اندام (BMI) \\
\hline$\Delta / \Psi \wedge \pm$ & $Y Y / 9 q$ & مهارتهاى حركتى ظريف \\
\hline$r / v q \pm$ & $Y Q / 94$ & مهارت هاى حركتى درشت \\
\hline$N / \mu I \pm$ & MN/GT & مهارتهاى حركتى كل \\
\hline$r / 0 \cdot \pm$ & $\Lambda / \wedge$. & شرايط بدنى \\
\hline$r / 91 \pm$ & $9 / \mu$. & انعطافيذيرى \\
\hline
\end{tabular}




\begin{tabular}{|c|c|c|}
\hline$r / T I \pm$ & $\Lambda / 91$ & شرايط عضلانى \\
\hline $1 / V 1 \pm$ & $\Lambda / \wedge \vee$ & تركيب بلدنى \\
\hline $9 / 99 \pm$ & $r \Delta / \Delta /$ & شايستخى جسمانى \\
\hline $1 / V 9 \pm$ & $9 / \pi T$ & جو ادارك شده از سوى معلمان \\
\hline $1 / \wedge \vee \pm$ & V/AT & جو ادراى شده از سوى همسالان \\
\hline$r / 99 \pm$ & $14 / \cdot 0$ & جو ادراى شده از محيط فيزيكى \\
\hline $1 / 91 \pm$ & $\Lambda / A V$ & حمايت اجتماعى دوستان \\
\hline$T / \wedge \Delta \pm$ & $\mid r / Q Y$ & حمايت اجتماعى خانواده \\
\hline$\Gamma / \Lambda \perp \pm$ & $r \mu / \mu i$ & جو ادراك شده از محيط اجتماعى \\
\hline $9 / 99 \pm$ & $\mid+1 / r \Lambda$ & فعاليت بلدنى \\
\hline
\end{tabular}

براى بررسى رابطه متغيرهاى تحقيق با ميزان فعاليت بدنى كودكان از ضريب كشتاورى بيرسون استفاده شده است. جدول (Y)

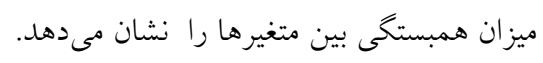

\begin{tabular}{|c|c|}
\hline ضريب همبستى & بايه تحصيلى \\
\hline$-\cdot / I V \mu^{*}$ & تناسب اندام (BMI) \\
\hline$\cdot /<+q \% *$ & مهارتهاى حركتى ظريف \\
\hline - MYG*** & مهارتهاى حركتى درشت \\
\hline$\cdot / \times Y \varphi^{* * * *}$ & مهارتهاى حركتى كل \\
\hline$\cdot / 4 \Delta \wedge * \%$ & شرايط بدنى \\
\hline$\cdot \pi 1 \cdot * * *$ & انعطاف يذيرى \\
\hline$\cdot /|0|^{* * *}$ & شر ايط عضلانى \\
\hline.$/ 1 \mathrm{Y}^{*}$ & تركيب بلنى \\
\hline$\cdot \mu V V^{* * *}$ & شايستگى جسمانى \\
\hline$\cdot \pi 40 \% *$ & جو ادارى شده از سوى معلمان \\
\hline$\cdot \mu V \cdot * *$ & جو ادراى شده از سوى همسالان \\
\hline$\cdot / 4 \vee \mu^{* \% *}$ & جو ادراك شده از محيط فيزيكى \\
\hline$\cdot \pi 49 \%$ & حمايت اجتماعى دوستان \\
\hline$\cdot \pi V \Lambda^{* * * *}$ & حمايت اجتماعى خانواده \\
\hline$\cdot / 40 \cdot * 3$ & جو ادراى شده از محيط اجتماعى \\
\hline & در سطح 1. \\
\hline
\end{tabular}


يافتها نشان داد بين تناسب اندام كودكان با ميزان فعاليت بدنى آنها رابطه مثبت معنىدارى وجود دارد (P<.01). يعنى هر جهه

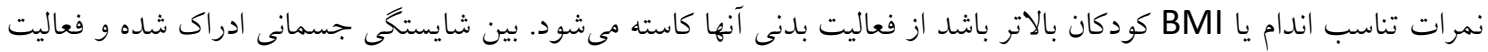
بدنى كودكان رابطه معنادارى وجود دارد (P>01). در اين بين، شرايط بلنى، انعطاف يذيرى، شرايط عضلانى و تركيب بدنى بانيا

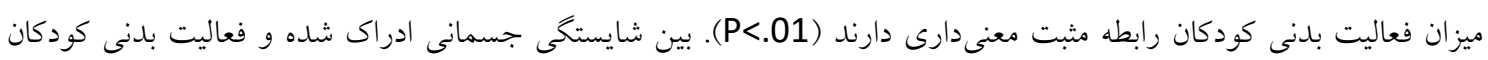

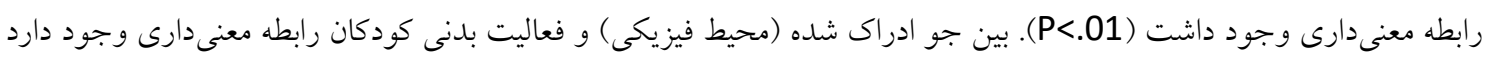
(P<.01). در اين بين، جو ادراك شده از سوى معلمان و جو ادراك شده از سوى همسالان با ميزان فعاليت بدنى كودكان رابطه

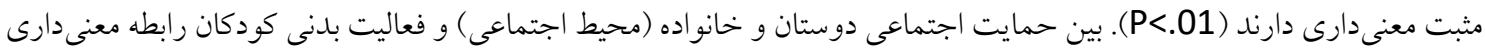

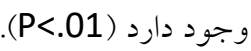

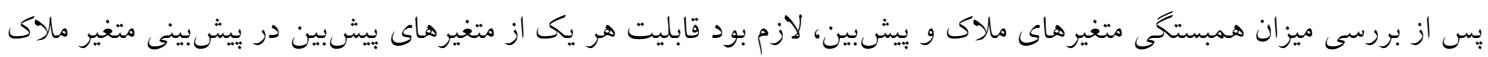

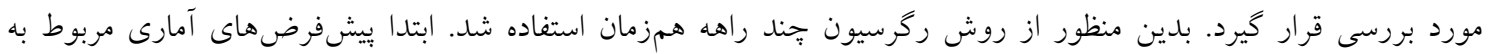

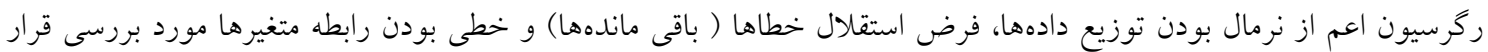
كرفته وتأييد شد. با توجه به مقدار آماره دوربين واتسون (Durbin Watson=0.67) فرض استقلال خطاها تأييد شد. ضريب رخرسيونى رابطه

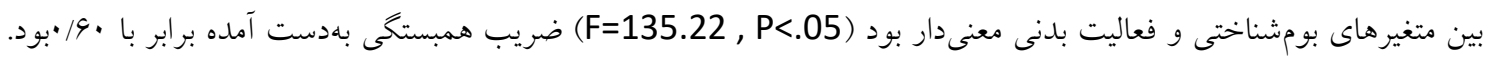

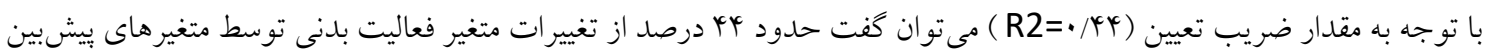
قابل تبيين است.

جدول r. مشخص كنندهاى آمارى رگر سيون جند كانه به منظور بيشبينى فعاليت بدنى كود كان از روى متغيرهاى بيشبين

\begin{tabular}{|c|c|c|c|c|c|}
\hline سطح معنى دارى & $\mathrm{t}$ & مضريب & خطاى معيار & B ضريب B & \\
\hline$\cdot \cdots 1$ & $1 \cdot / v \vee q$ & - & r/OrY & $r N \cdot 9 \mathrm{~V}$ & عرض از مبدا \\
\hline.$\cdots 1$ & $\Lambda / \Gamma \Delta \Delta$ & $-\cdot / 1 \cdot 1$ & $\cdot / \cdot \mu$ & $-\cdot /$ kr & تناسب اندام \\
\hline.$/ \cdot 1$ & $1 \% / 919$ & .1149 & .1 .44 & $\cdot / 019$ & شايستكى جسمانى \\
\hline.$/ \cdot 1$ & $\Lambda / V \& V$ & $\cdot /|r|$ & $\cdot / \cdot \Delta r$ & $. / 4+q$ & مهارتهاى حركتى \\
\hline.$\cdots 1$ & rGKMG & $\cdot / Y M Y$ & .1119 & $\cdot / V Q Q$ & محيط فيزيكى \\
\hline.$/ \cdots 1$ & G/ArI & $\cdot / T K Y$ & .1 .91 & .194. & محيط اجتماعى \\
\hline
\end{tabular}

با توجه به معادله رگرسيون با ضرايب استاندارد جدول ب، تناسب اندام •ا درصد، شايستخى جسمانى 10 درصد و مهارتهاى

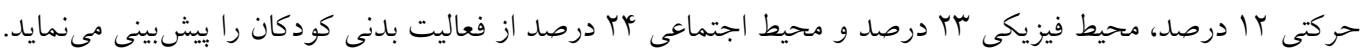
شكل (1) بيانكر ضرايب اثر مستقيم ركرسيونى متغيرهاى تناسب اندام، شايستىى جسمانى، مهارتهاى حركتى، محيط فيزيكى و محيط اجتماعى بر ميزان فعاليت بدنى آزمودنى هاست 


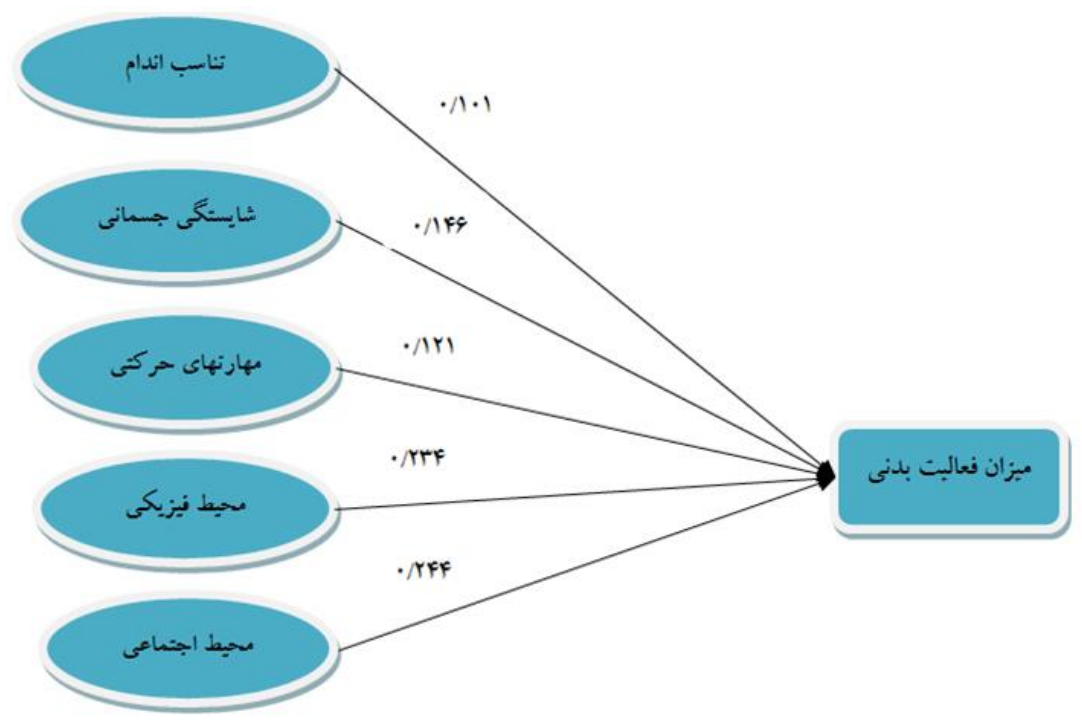

متغيرهاى ييشبينى كننده ميزان فعاليت بدنى دختران شكل (1): ضرايب اثر مستقيم رخرسيونى

\section{بحث و نتيجه تيرى}

اين تحقيق با استفاده از رويكرد بومشناختى به منظور بيشبينى فعاليت بلدنى كودكان دختر انجام شد و از نتايج آن مى توان به به منظور

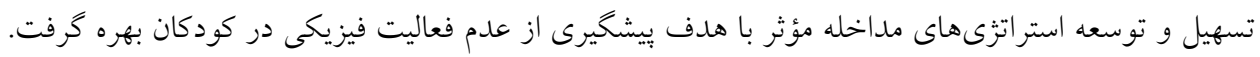

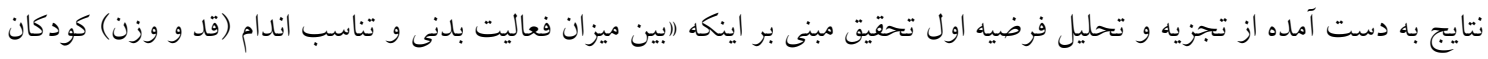

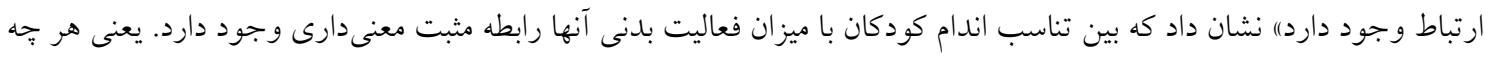

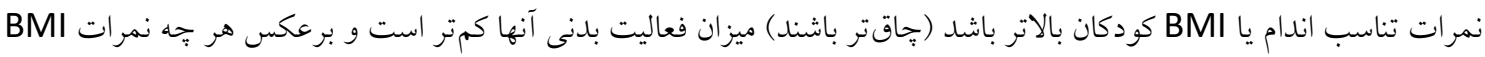

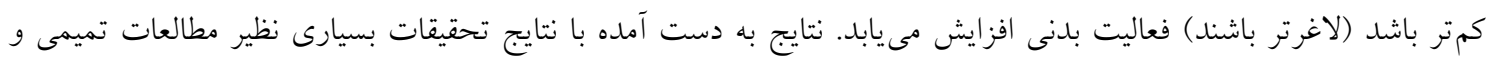

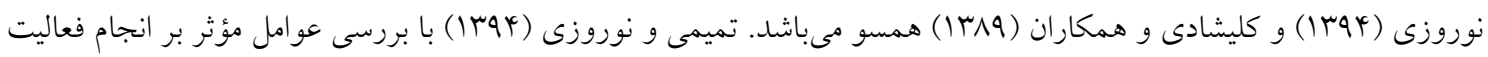

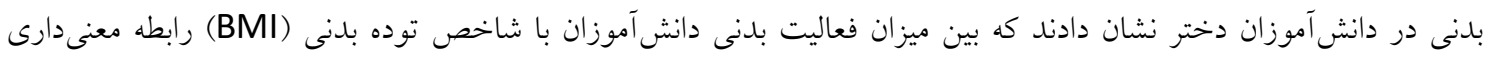

وجود دارد (r. (r).

نتايج به دست آمده از تجزيه و تحليل فرضيه دوم تحقيق مبنى بر اينكه (ابين ميزان فعاليت بدنى و شايستكى جسمانى ادراك شداه

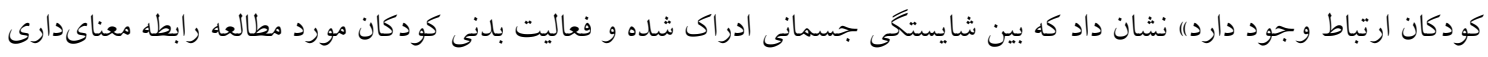

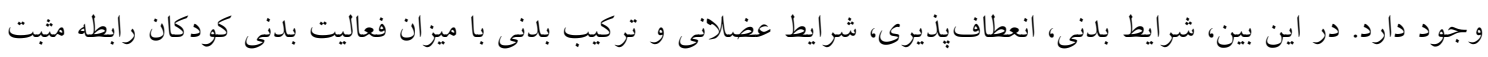

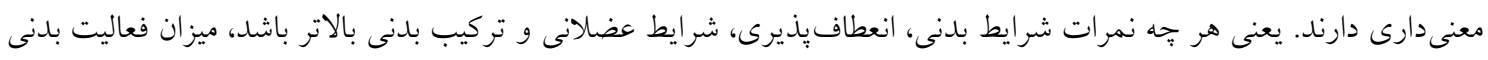

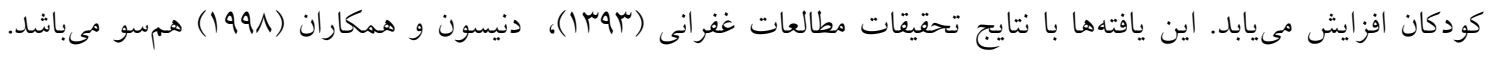

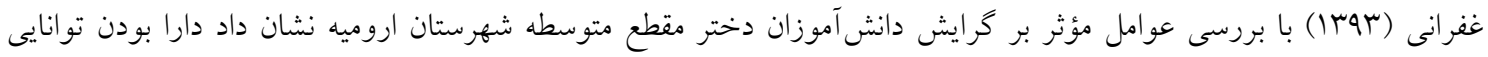
جسمى و مهارت ورزشى با ميزان فعاليت بدنى در ارتباط است (اسب) .

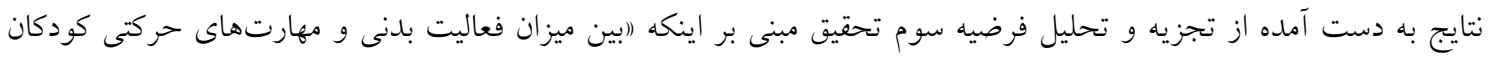

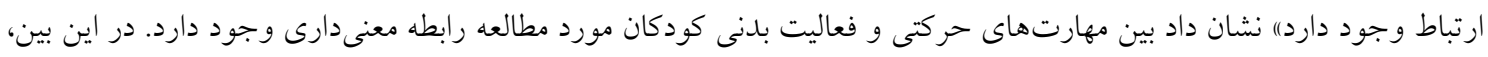

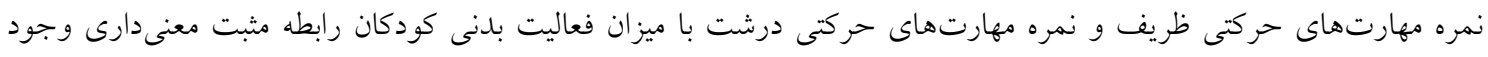

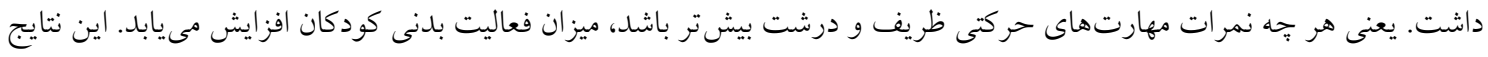

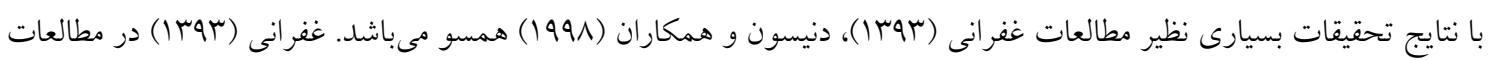

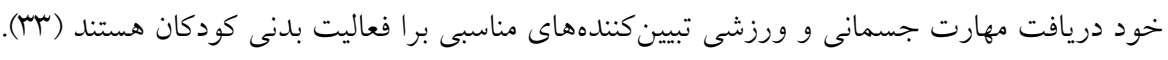


نتايج به دست آمده از تجزيه و تحليل فرضيه سوم تحقيق مبنى بر اينكه (بيين ميزان فعاليت بدنى كودكان و محيط فيزيكى ارتباط

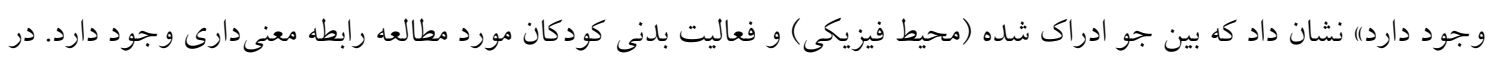

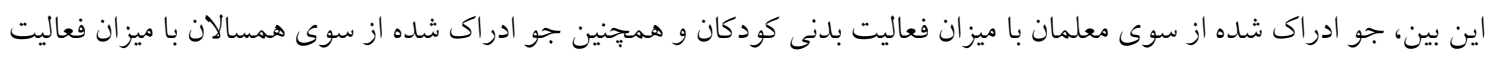

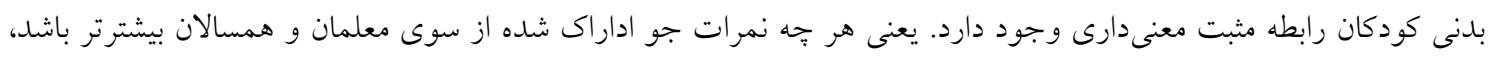

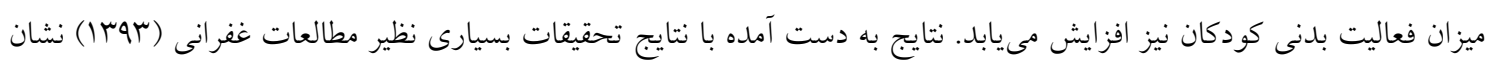

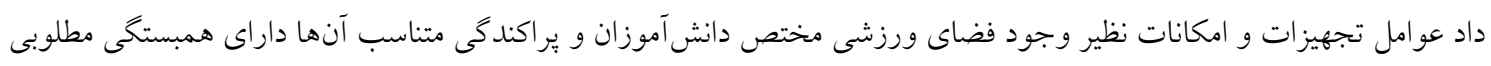

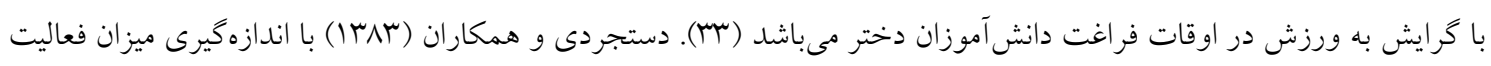

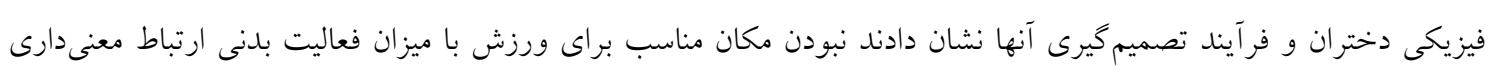

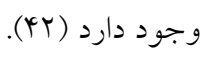

نتايج به دست آمده از تجزيه و تحليل فرضيه بنجم تحقيق مبنى بر اينكه (بيين ميزان فعاليت بدانى كودكان و محيط اجتماعى ارتباط

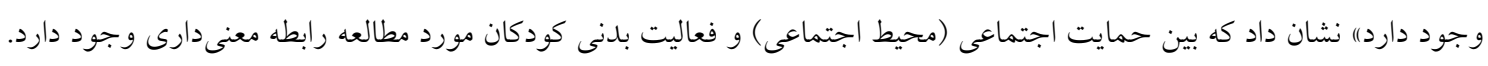

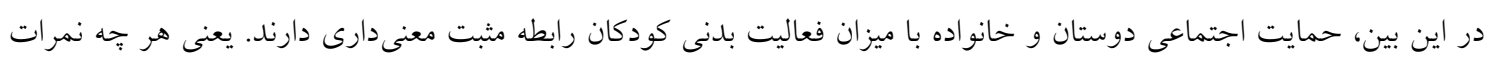

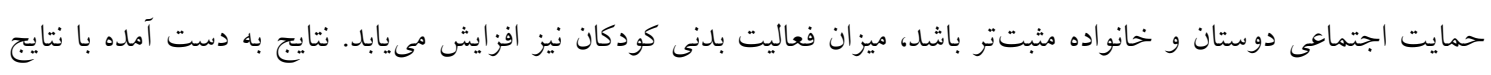

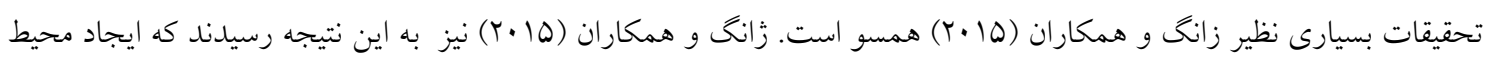

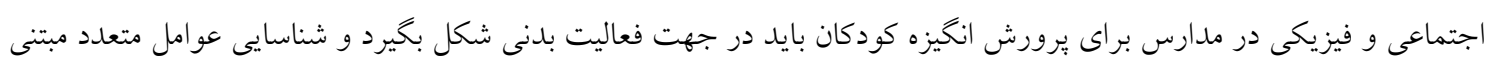

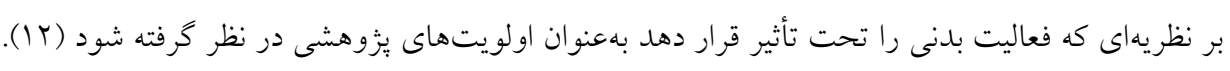

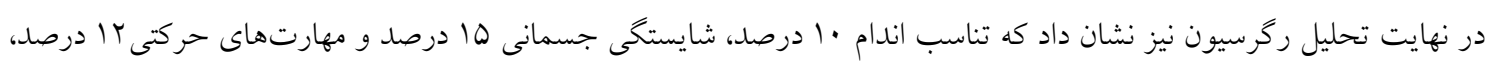

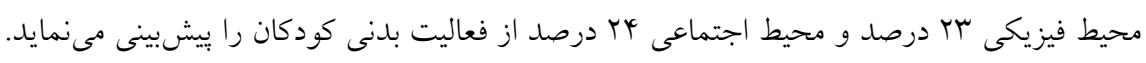

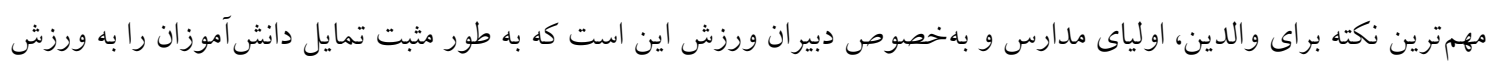

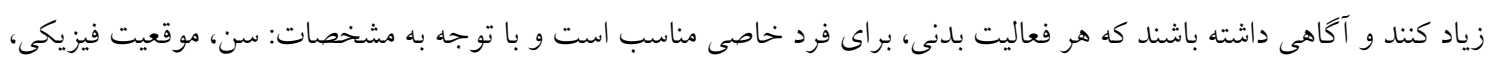

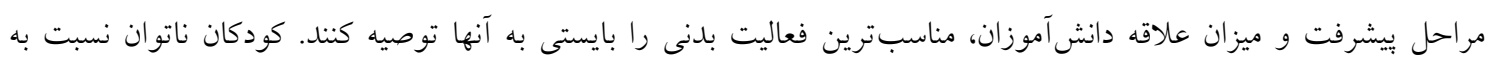

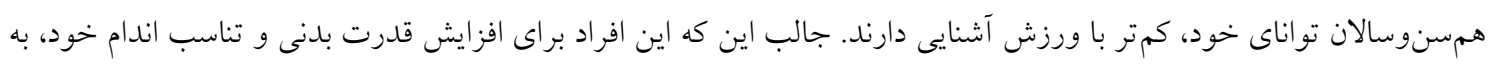

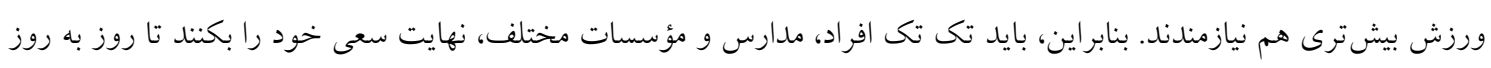

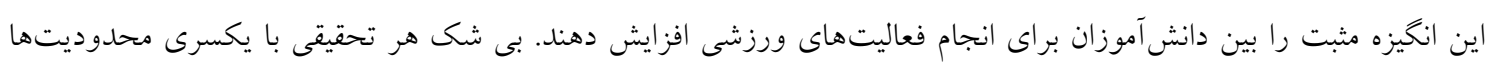

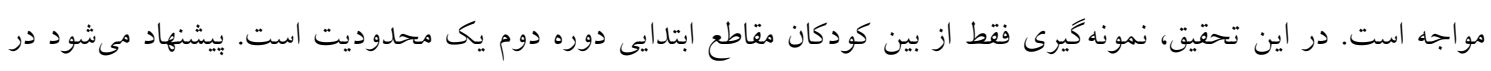

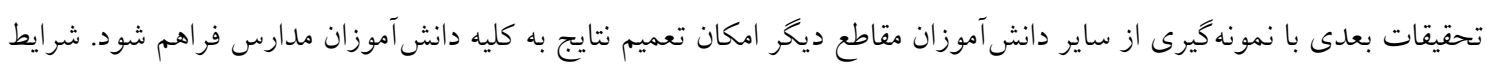

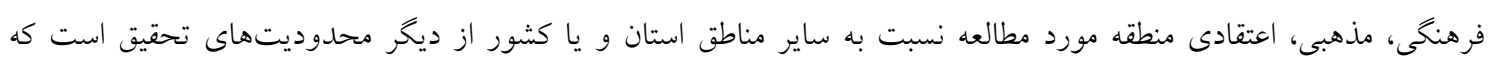

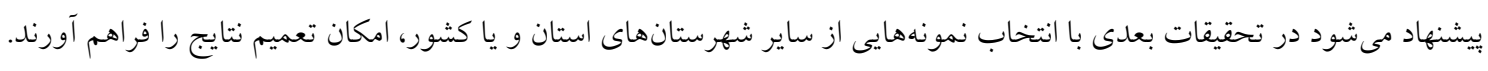

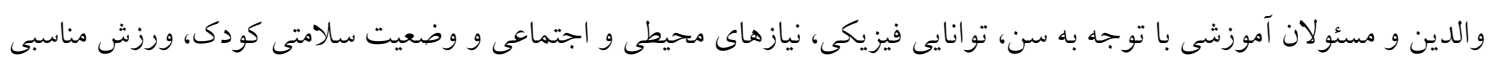

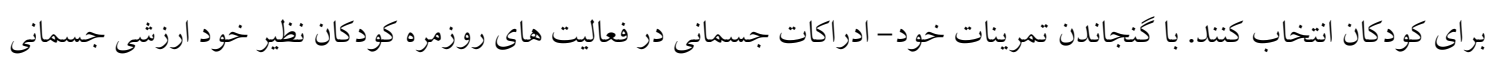

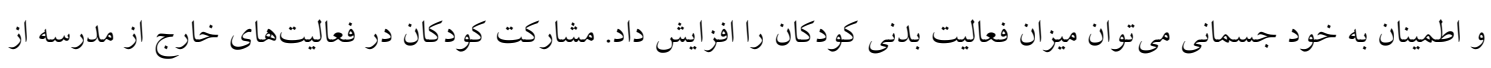

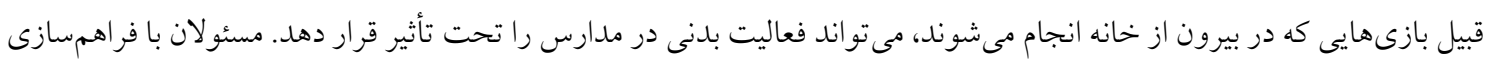

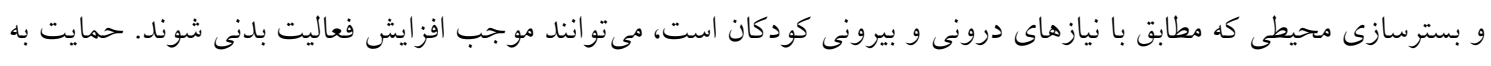

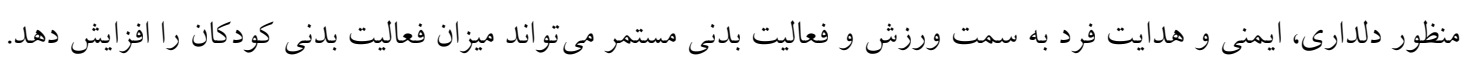

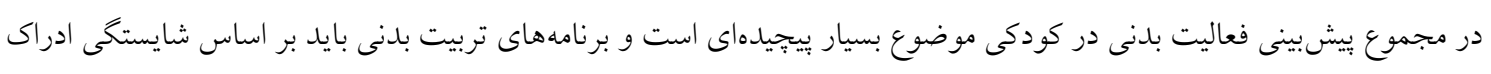

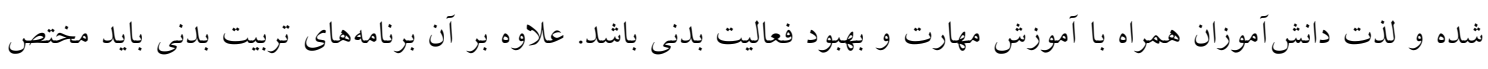

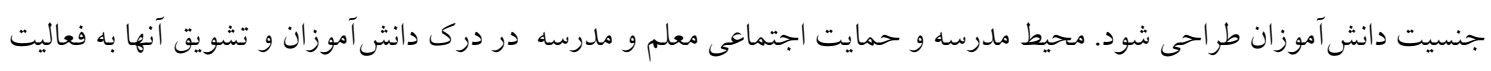




$$
\text { فرانى بسيار مؤثر است. معلمان ورزش بايد براى بهبود شايستكى ادراك شده تمرينات و بازخورد بيشترى را براى دانش آموزان }
$$

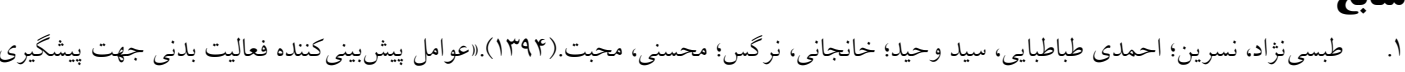

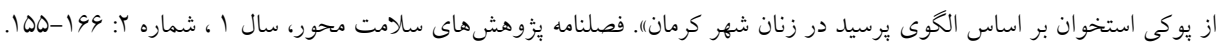

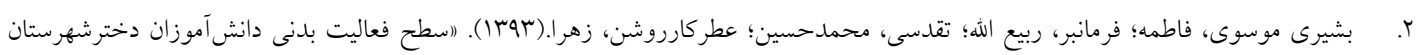

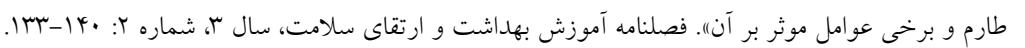

3. Chan Sun M, Azmutally KB.(2013). Leisure-time physical activity among university students in Mauritius. Am J Health Res; 1(1): 1-8.

4. McAuley,E., Kramer, A. F., and Stanley J.(2004) Colcombe, E; Kramer, Arthur F; Colcombe, Stanley J . "Cardiovascular fitness and neurocognitive function in older Adults: a brief review". BRAIN, BEHAVIOR, and IMMUNITY.18 (2004): 214-220.

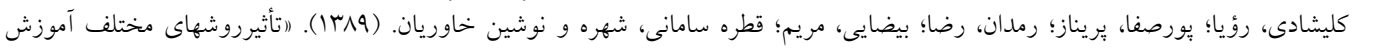

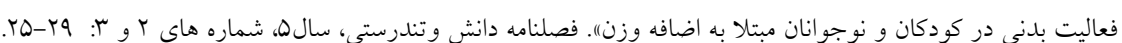

6. Kelishadi, R., Razaghi, EM., Gouya, MM., Ardalan, G., Gheiratmand, R.,Delavari, A., et al.(2007). Association of physicalactivity and the metabolic syndrome in children and adolescents: CASPIAN Study ;67(1):46-52.

7. Kelder, SD., Perry, CL., Klerr, KI., Lytle, LL.(1994). Longitudinal tracking of adolescents smoking, physical activity, and food chiose behaviors. Am J Public Health;84:1121-6 .

8. Dietz W.(2001). The obesity epidemic in young children. British Med J;322:313-4.

9. Azizi, F., Allahverdian, S., Mirmiran, P., Rahmani, M., Mohammadi, F. (2001). Dietary factors and body mass index in a group of Iranian adolescents: Tehran lipid and glucose study. Int J Vitam Nutr Res; 71(2):123- 7.

10. National Association for Sport and Physical Education. (2010). PE Metrics: Assessing national standards 1-6 in elementary school Reston, VA: Author.

11. Daley, A.J. (2002). School based physical activity in the United Kingdom: Can it create physically active adults? Quest, 54, 21-33.

12. McKenzie, T.L. (2001). Promoting physical activity in youth: Focus on middle school environments.Quest, 53, 326-334.

13. Zhang,T., Thomas,K., Weiller,K.(2015). Predicting Physical Activity in 10-12 Year Old Children: A Social Ecological Approach. Journal of Teaching in Physical Education, 34, 517-536.

14. Stokols, D. (1996). Translating social ecological theory into guidelines for community health promotion. American Journal of Health Promotion, 10, 282-298.

15. Welk, G.J. (1999). The youth physical activity promotion model: A conceptual bridge between theory and practice. Quest, 51, 5-23.

16. Sallis JF, Prochaska JJ, Taylor WC.A .(2000). review of correlates of physical activity of children and adolescents. Med Sci Sports Exerc; 32(5): 963-75.

$$
\begin{aligned}
& \text { VV }
\end{aligned}
$$

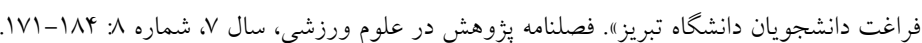

18. Buckworth,J., Dishman, R.K. (2002). Determinants of exercise and physical activity.Exercise psychology, pp.191-209.

19. Tammelin, T., Nayha, S., Laitinen, J., Rintamaki, H., Jarvelin.M.R.(2003). Phsical activity and social status in adolescence as predictors of physical inactivity in adulthood. Preventive Medicne, 37: 375381.

20. Castelli, D. M., Valley, J. A. (2007). Chapter 3: The relationship of physical fitness and motor competence to physical activity. Journal of Teaching in Physical Education, 26(4):358-374.

21. Dennison, B.A., Straus, J.H., Mellits, E.D., Charney, E. (1998). Childhood physical fitness tests: Predictor of adult physical activity levels? Pediarics, 82: 324-330.

22. Drummond, J.L.(1996). Type of physical activity.Variables describing participation in phsycal activity, and self-perceived fitness. Perceptual and Motor Skills, 83: 472-474.

23. Sarr, M., Jurimae,T.(2007). Sports participation outside school in total physical activity of children. Perceptual and Motor Skills, 105: 559-562.

24. Millstein, R. A., Strobel, J., Kerr, J., Sallis, J. F., Norman, G. J., Durant, N., Saelens, B. E. (2011). Home, school, and neighborhood environment factors and youth physical activity. Pediatric exercise science, 23(4): 487-503. 
25. Adesoye, A. A., Obiyemi, O. O., Ibraheem, T. O., \& Ajibua, M. A. (2017). Gender gap in social environment of leisure- time physical activity of university students in southwest Geo-political zone of Nigeria. Choregia: Sport Management International Journal, 13(1), 33-49.

26. Kim, J. Ma, M. Akira. (2017). Factors impacting levels of physical activity and sedentary behavior among young children:a literature review. International Journal of Applied Sports Sciences, 29(1): 1-12.

27. Barnett, L. M., van Beurden, E., Morgan, P. J., Brooks, L. O., \& Beard, J. R. (2010). Gender differences in motor skill proficiency from childhood to adolescence: A longitudinal study. Research quarterly for exercise and sport, 81(2): 162-170.

28. Haga, M. (2008). The relationship between physical fitness and motor competence in children. Child: care, health and development, 34(3):329-334

29. Franzini, L., Elliott, M. N., Cuccaro, P., Schuster, M., Gilliland, M. J., Grunbaum, J. A. Tortolero, S. R. (2009). Influences of physical and social neighborhood environments on children's physical activity and obesity. American journal of public health, 99(2): 271-278.

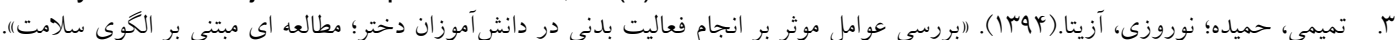

مجله سلامت و بهداشت، سال 9، شماره ه: DrN-QHV.

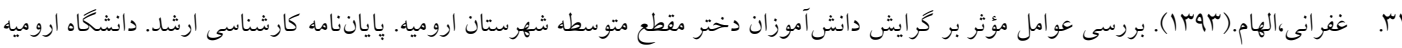

: دانشكده تربيت بدنى و علوم ورزشى.

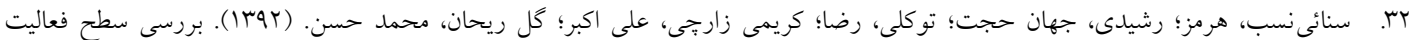

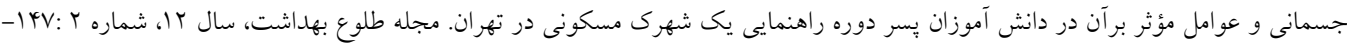

33. Ihmels MA, Welk GJ, Eisenmann JC, et al.(2009). Development and preliminary validation of a Family Nutrition and Physical Activity (FNPA) screening tool. Int J Behav Nutr Phys Act 12; 6: 14.

34. Wagner A, Klein-Platat C, Arveiler D, et al.(2004). Parent-child physical activity relationships in 12-year old French students do not depend on family socioeconomic status. Diabetes Metab; 30(4): 359-66 .

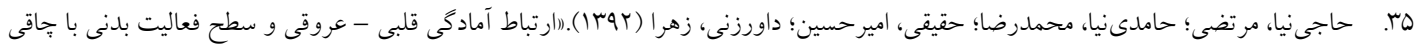

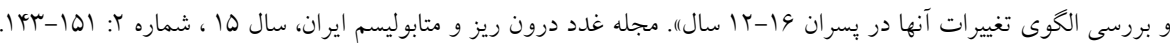

36. Farmanbar R, Niknami S, Heydarnia A,Hajizadeh E, Lubans DR.(2009). Predicting exercise behavior among Iranian college students using the Transtheoretical Model and structural equation modeling| NOVA. The University of Newcastle's Digital Repository; 31(3): 355-65.

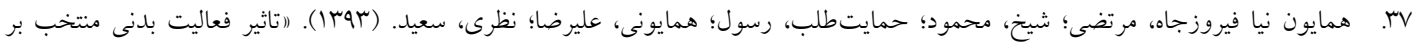

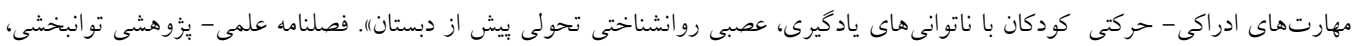

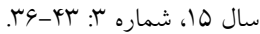

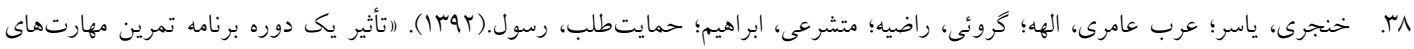

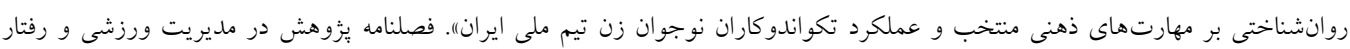

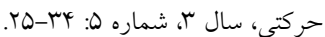

39. Abadie, B. R. (1998). Relating trait anxiety to perceived physical fitness. Perceptual and Motor Skills, 67, 887-892.

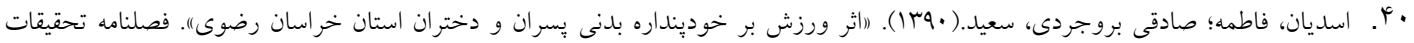

$$
\begin{aligned}
& \text { علوم ورزشى، سال ז، شماره ه: }
\end{aligned}
$$

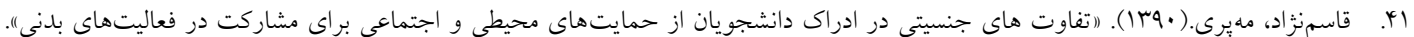

$$
\begin{aligned}
& \text { فصلنامه رفتار حركتى و روانشناسى ورزشى، سال 1، شماره V: • •V9. }
\end{aligned}
$$

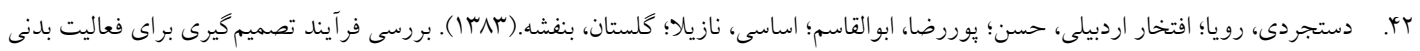

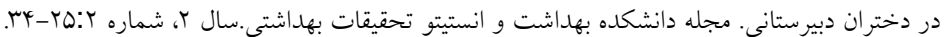

